\title{
A new species of Cirolana Leach, 1818 (Isopoda, Cymothoidea, Cirolanidae) from Brazilian coast
}

\author{
Ricardo J.C. Paiva and Jesser F. Souza-Filho
}

Museu de Oceanografia Petrônio Alves Coelho, Universidade Federal de Pernambuco, Laboratório de Carcinologia. Av. Arquitetura, s/n, Cidade Universitária, CEP 50740-550, Recife, Pernambuco, Brazil.E-mail: (RJCP) ricardopaiva_5@hotmail.com; (JFSF) jesser_fidelis@yahoo.com.br

\begin{abstract}
A new species of Cirolana is described from the Northeast Brazilian coast based on the material previously recorded as Cirolana palifrons and some other material misidentified as $C$. parva. The new species, C. lemoscastroi sp. nov., belongs to a group of species within the genus that have two dorsal longitudinal carinae on the pleotelson. A key to all Cirolana species recorded from Brazil is provided.
\end{abstract}

Key words: Benthic fauna, benthic isopod, marine species, new taxa, taxonomy

\section{INTRODUCTION}

The Cirolanidae are worldwide distributed isopods, including marine, estuarine and some freshwater species. Most cirolanids are marine free-living carnivores or scavengers feeding on the carcasses of animals they have not captured and killed themselves (Keable, 1998; Stepien and Brusca, 1985; Bruce, 1986a; Berrow, 1994). Some species are opportunistic and aggressive biting other animals (Miller, 1968).

The genus Cirolana Leach, 1818 is the most diverse genus with at least 135 described species within the family Cirolanidae. Nevertheless, the literature on this genus from Brazilian waters remains sparse (Koening, 1972; Lemos de Castro and Lima, 1976; PiresVanin, 1998; Almeida et al., 2009). Hitherto, only five species had been recorded from coast of Brazil, Cirolana (Anopsilana) browni (Van Name, 1936), C. minuta Hansen, 1890, C. (A.) jonesi (Kensley, 1987), C. palifrons Barnard, 1920 and C. parva Hansen, 1890. Cirolana (A.) browni was reported from Pernambuco and Paraíba estuarine areas by Coelho et al. (1970). Cirolana minuta was cited by Coelho et al. (1980) from Amapá State (Northern Region). Koening (1972) recorded C. parva, originally described from the Caribbean Sea, from the States Amapá to Espírito Santo. In both records, the authors did not provide any illustration of the examined material. Later on, Cirolana palifrons, originally described from South Africa, was recorded from the coast Bahia and Espírito Santo by Lemos de Castro and Lima (1976). These authors found some differences between the Brazilian specimens and Barnard's (1920) description (e.g. antenna length and shape of rostrum), but although this record constitutes an extralimital distribution, they considered the differences only as morphological variations. Recently, Almeida et al. (2009) reported the Caribbean species $C$. (A.) jonesi for the first time from Bahia Coast extending its distribution to Brazil.

In this paper, we re-examined material recorded as $C$. parva and $C$. palifrons from Brazilian coast. After new evaluation of these collections and with additional material from other localities along the Brazilian Coast, we observed two important points: (a) all the specimens identified as $C$. palifrons, including the specimens studied by Lemos de Castro and Lima (1976); and, (b) some lots identified as C. parva belong to a new species of Cirolana described in this paper. 


\section{Material and Methods}

The specimens examined in this study were collected by different expeditions along the Northeast Brazilian coast. The specimens were observed under a stereoscopic microscope with a camera lucida and the drawn specimens were dissected and mounted in glycerine gel slides, after staining with clorazol black. Digital illustrations were made up according to Coleman (2003). The type material is deposited in the Crustacea collection of "Museu de Oceanografia Prof. Petrônio Alves Coelho da Universidade Federal de Pernambuco" (MOUFPE) and "Museu Nacional da Universidade Federal do Rio de Janeiro" (MNRJ).

List of abbreviation used in the text and figures: An, antennule; Ant, antenna; BPOT, Bacia Potiguar; C, clypeus; HA, habitus; FL, frontal lamina; $\mathrm{Md}$, mandible; $\mathrm{Ml}$, maxillula; Mx, maxilla; Mxp, maxilliped; P, pereopod; Pn, penis; PL, pleopod; Urs, urosomite; U, uropod; T, Telson; d, dorsal view; l, lateral view, $\mathrm{m}$, male.

\section{Systematics \\ Suborder Cymothoida Wägele, 1989 \\ Superfamily Cymothoidea Leach, 1814 \\ Family Cirolanidae Dana, 1852 Genus Cirolana Leach, 1818}

Cirolana Leach, 1818: 347. -Sars 1897: 69. -Brusca, 1980: 228. -Holdich et al., 1981: 557. -Brusca and Iverson, 1985: 35. - Bruce, 1986: 139. -Kensley and Schotte, 1987: 227. -Brusca et al., 1995: 17.

Type species - Cirolana cranchii Leach, 1818.

Diagnosis: See Brusca and Iverson (1985); Bruce, (1986b); Brusca et al. (1995).

\section{Cirolana lemoscastroi sp. nov.}

(Figs. 1-5)

Cirolana palifrons -Lemos de Castro \& BrasilLima, 1976: 77, figs. 1-14; Pires-Vanin, 1998: 609 (not Cirolana palifrons Barnard, 1920). Cirolana parva-Koening, 1972: 240 (partim; not Cirolana parva Hansen, 1890).

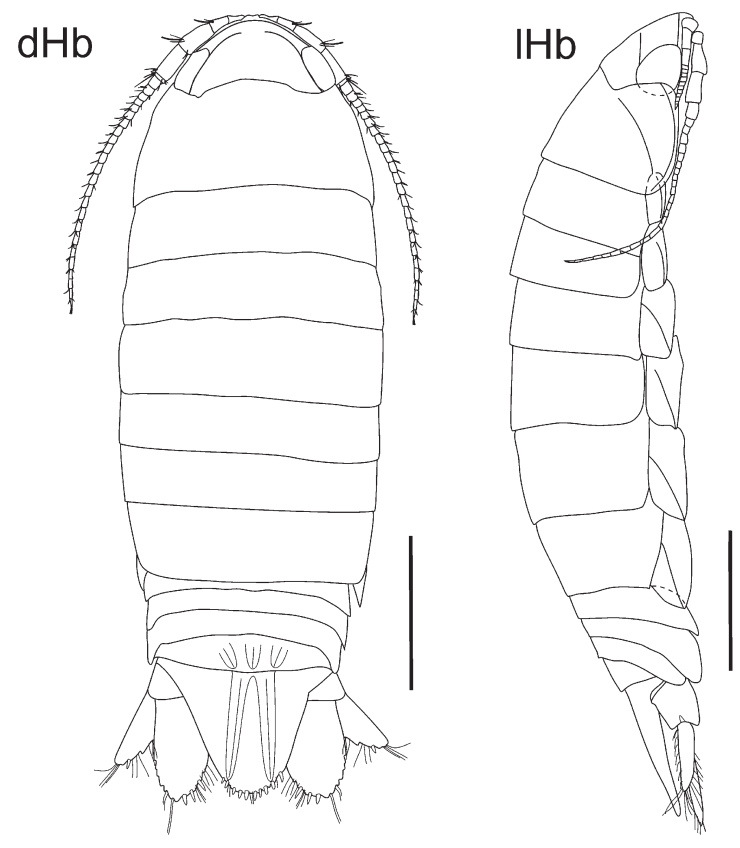

Figure 1. Cirolana lemoscastroi sp. nov., habitus of holotype female $(5.1 \mathrm{~mm})$ in lateral and dorsal view (pigmentation not shown), BPOT IV 37 ( $4^{\circ} 57^{\prime \prime} 48^{\prime \prime}$ - 36 $\left.46^{\circ} 15^{\prime \prime W}\right)$, off Potiguar Basin, Rio Grande do Norte, MOUFPE 14956. Scale bars: $1.0 \mathrm{~mm}$.

Etymology. In honor to Dr. Alceu Lemos de Castro for his contribution to the knowledge of Brazilian isopod fauna.

Material examined. Holotype. Female (dissected and illustrated, $5.1 \mathrm{~mm}$ ), BPOT IV 37, dredge, 457"48”S - 3644'15”W, off Potiguar Basin, Rio Grande do Norte, $10 \mathrm{~m}$ depth, 30 May 2004, N/RB Astro Garoupa, MOUFPE 14956.

Paratypes. Male (dissected and illustrated, $4.3 \mathrm{~mm}$ ), BPOT IV 37, dredge, 4⒌"48”S - 364'15”W, off Potiguar Basin, Rio Grande do Norte, $10 \mathrm{~m}$ depth, 30 May 2004, N/RB Astro Garoupa, MOUFPE 14957.1 male $(6 \mathrm{~mm})$, SUDEPE \#52, $18^{\circ} 24^{\prime} \mathrm{S}$ - 39 $12^{\prime} W$, Vessel Riobaldo col., 10 April 1974, MNRJ 6439 (previously identified as $C$. palifrons by Lemos de Castro and Lima, 1976). 1 female, BPOT IV 37, dredge, 457"48"S $36^{\circ} 44^{\prime} 15^{\prime} \mathrm{W}$, off Potiguar Basin, Rio Grande do Norte, 10 m depth, 30 May 2004, N/RB Astro Garoupa, MOUFPE 14955. 18 males, 9 females and 6 ovigerous female, BPOT IV 37, dredge, 45 "48"S - 36 44'15"W, off Potiguar Basin, Rio Grande do Norte, $10 \mathrm{~m}$ depth, 30 May 2004, N/RB Astro Garoupa, MOUFPE 


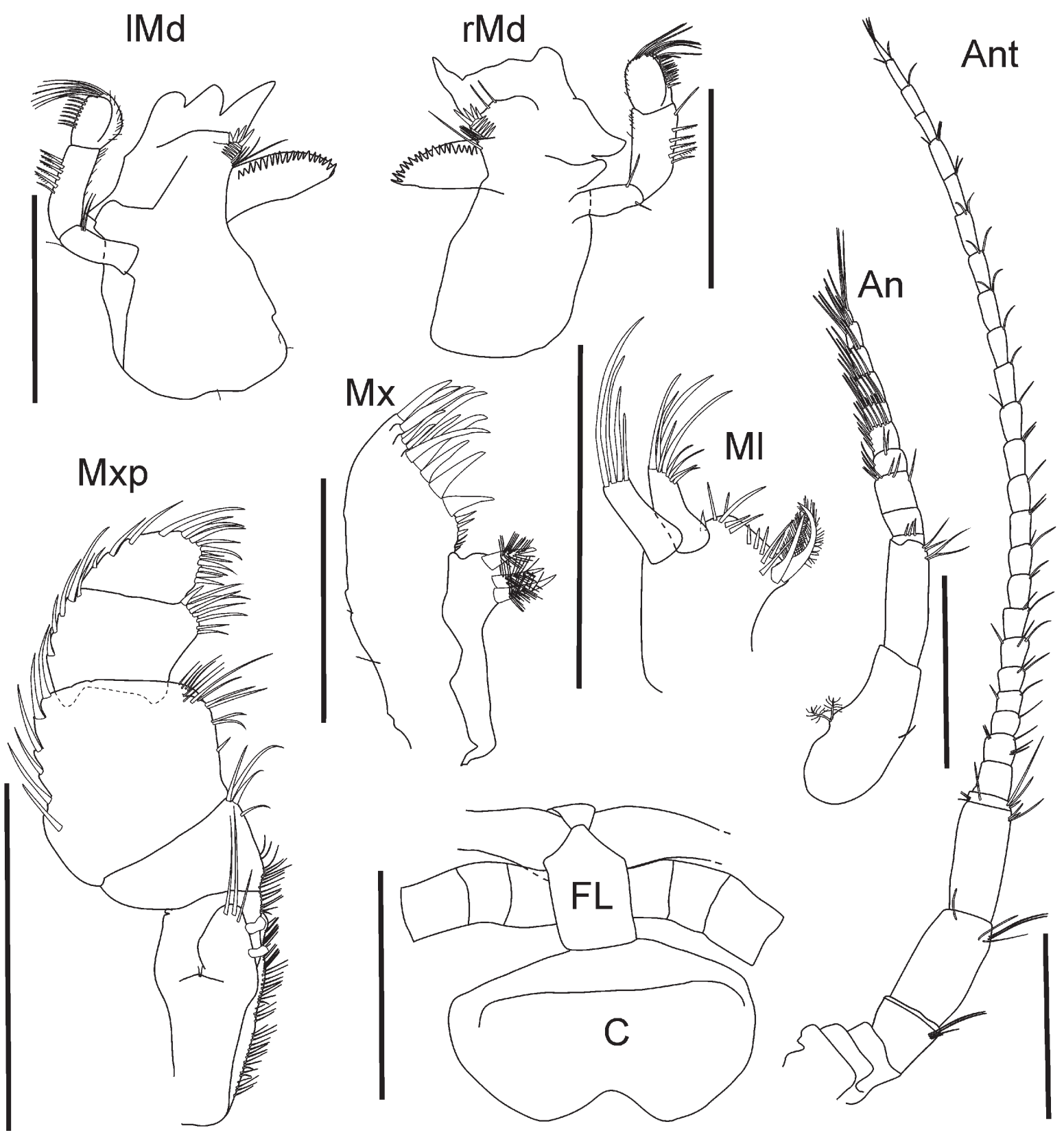

Figure 2. Cirolana lemoscastroi sp. nov., holotype, female $(5.1 \mathrm{~mm})$ mouthparts, clypeus, frontal lamina and antennas, BPOT IV 37 (457"48”S - 3644'15”W), off Potiguar Basin, Rio Grande do Norte, MOUFPE 14956. Scale bars: 0.5 mm.

14824. 2 males and 2 females, BPOT I \#21B, van Veen, 458'19”S - 36³3'58”W, offPotiguar Basin, Rio Grande do Norte, $10 \mathrm{~m}$ depth, July 2002, N/RB Astro Garoupa, MOUFPE 14656. 1 ovigerous female, BPOT I \#37C, van Veen, 4⒌"48”S - 36 44'15”W, off Potiguar Basin, Rio Grande do Norte, $10 \mathrm{~m}$ depth, July 2002, N/RB Astro Garoupa, MOUFPE 14774. 1 ovigerous female, BPOT I \#7A, van Veen, 458'15"S - 36²17'44”W, off Potiguar Basin, Rio Grande do Norte, $11 \mathrm{~m}$ depth, July 2002, N/RB Astro Garoupa, MOUFPE
14764. 1 male and 1 female, BPOT I \#7A, van Veen, 45 $8^{\prime} 15^{\prime}$ S - 36 $17^{\prime} 44^{\prime}$ W, off Potiguar Basin, Rio Grande do Norte, $11 \mathrm{~m}$ depth, July 2002, N/RB Astro Garoupa, MOUFPE 14767. 1 female, BPOT I \#35A, van Veen, 447”31”S - 3644'49”W, off Potiguar Basin, Rio Grande do Norte, 19 m depth, July 2002, N/RB Astro Garoupa, MOUFPE 14768. 1 male, BPOT I \#22A, van Veen, 4'52'54"S 363' 59"W, off Potiguar Basin, Rio Grande do Norte, $11 \mathrm{~m}$ depth, July 2002, N/RB Astro Garoupa, MOUFPE 14777. 1 male and 


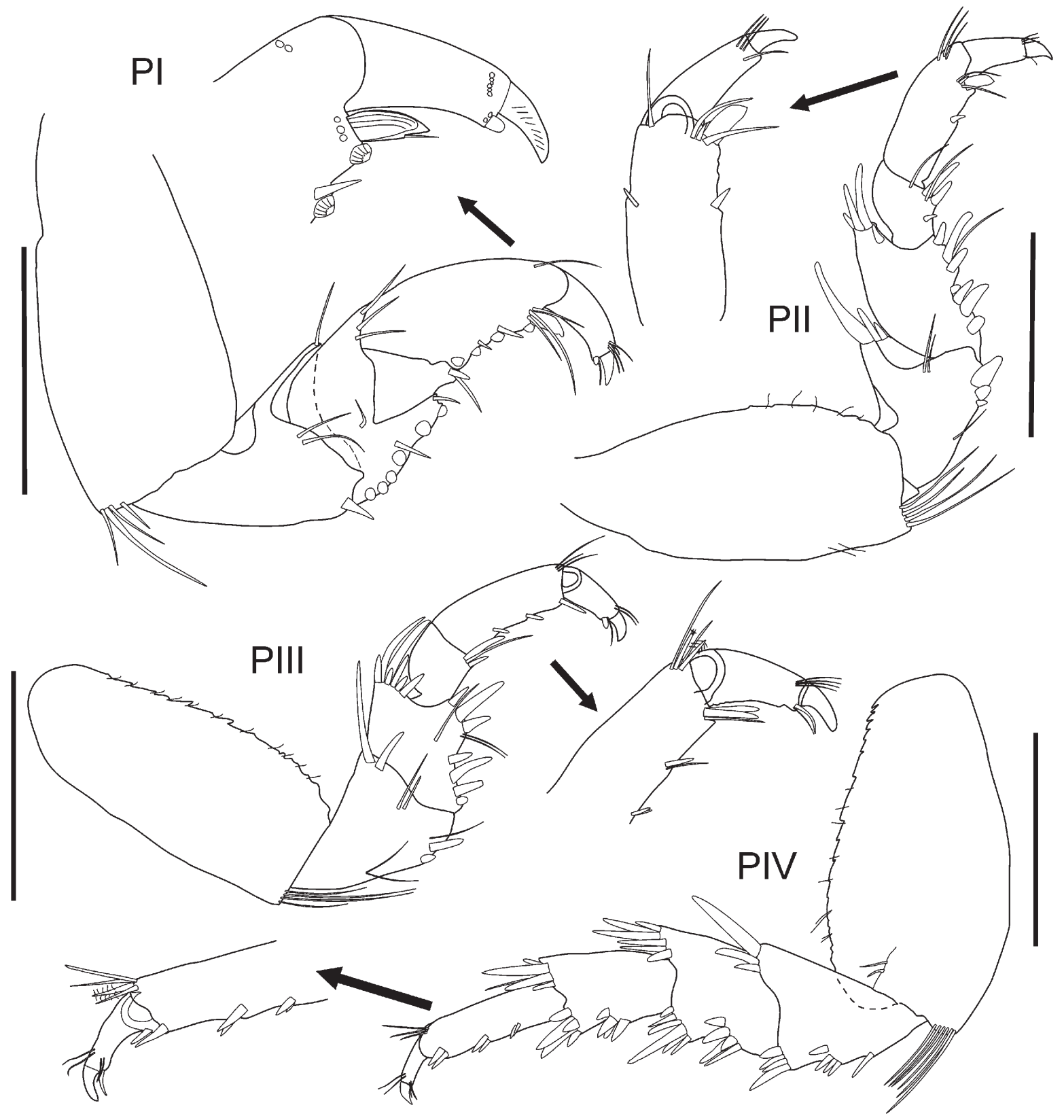

Figure 3. Cirolana lemoscastroi sp. nov., holotype, female ( $5.1 \mathrm{~mm})$, pereopods I-IV, BPOT IV 37 ( $\left.4^{\circ} 57^{\prime \prime} 48^{\prime \prime S}-36^{\circ} 44^{\prime} 15^{\prime \prime W}\right)$, off Potiguar Basin, Rio Grande do Norte, MOUFPE 14956. Scale bars: $0.5 \mathrm{~mm}$.

1 female, BPOT I \#21B, van Veen, $4^{\circ} 58^{\prime} 19^{\prime \prime}$ S - 36'33’5"'W, off Potiguar Basin, Rio Grande do Norte, 10 m depth, July 2002, N/RB Astro Garoupa, MOUFPE 14773. 1 ovigerous female, BPOT I \#7B, van Veen, 458’15”S $36^{\circ} 17^{\prime} 44^{\prime \prime} \mathrm{W}$, off Potiguar Basin, Rio Grande do Norte, $11 \mathrm{~m}$ depth, July 2002, N/RB Astro Garoupa, MOUFPE 14779. 1 male, BPOT III 37, dredge, $4^{\circ} 57^{\prime \prime} 48^{\prime \prime} \mathrm{S}-36^{\circ} 44^{\prime} 15^{\prime \prime} \mathrm{W}$, off Potiguar Basin, Rio Grande do Norte, 10 m depth, 16 November 2003, N/RB Astro Garoupa, MOUFPE 14784. 1 male, BPOT
III 18, dredge, 4058'18”S - 36 $28^{\prime} 33^{\prime \prime} \mathrm{W}$, off Potiguar Basin, Rio Grande do Norte, $12 \mathrm{~m}$ depth, November 2003, N/RB Astro Garoupa, MOUFPE 14786. 1 female, BPOT IV 37, dredge, 4⒌"48"S - 36 44'15"W, off Potiguar Basin, Rio Grande do Norte, $10 \mathrm{~m}$ depth, 30 May 2004, N/RB Astro Garoupa, MOUFPE 14813. 1 male, BPOT IV 21, 458'19"S $36^{\circ} 33^{\prime} 58^{\prime \prime} \mathrm{W}$, off Potiguar Basin, Rio Grande do Norte, 10 m depth, 28 May 2004, N/RB Astro Garoupa, MOUFPE 14802. 1 male, BPOT IV 20, dredge, $5^{\circ} 3^{\prime} 43^{\prime \prime} \mathrm{S}-36^{\circ} 33^{\prime} 57^{\prime \prime} \mathrm{W}$, 


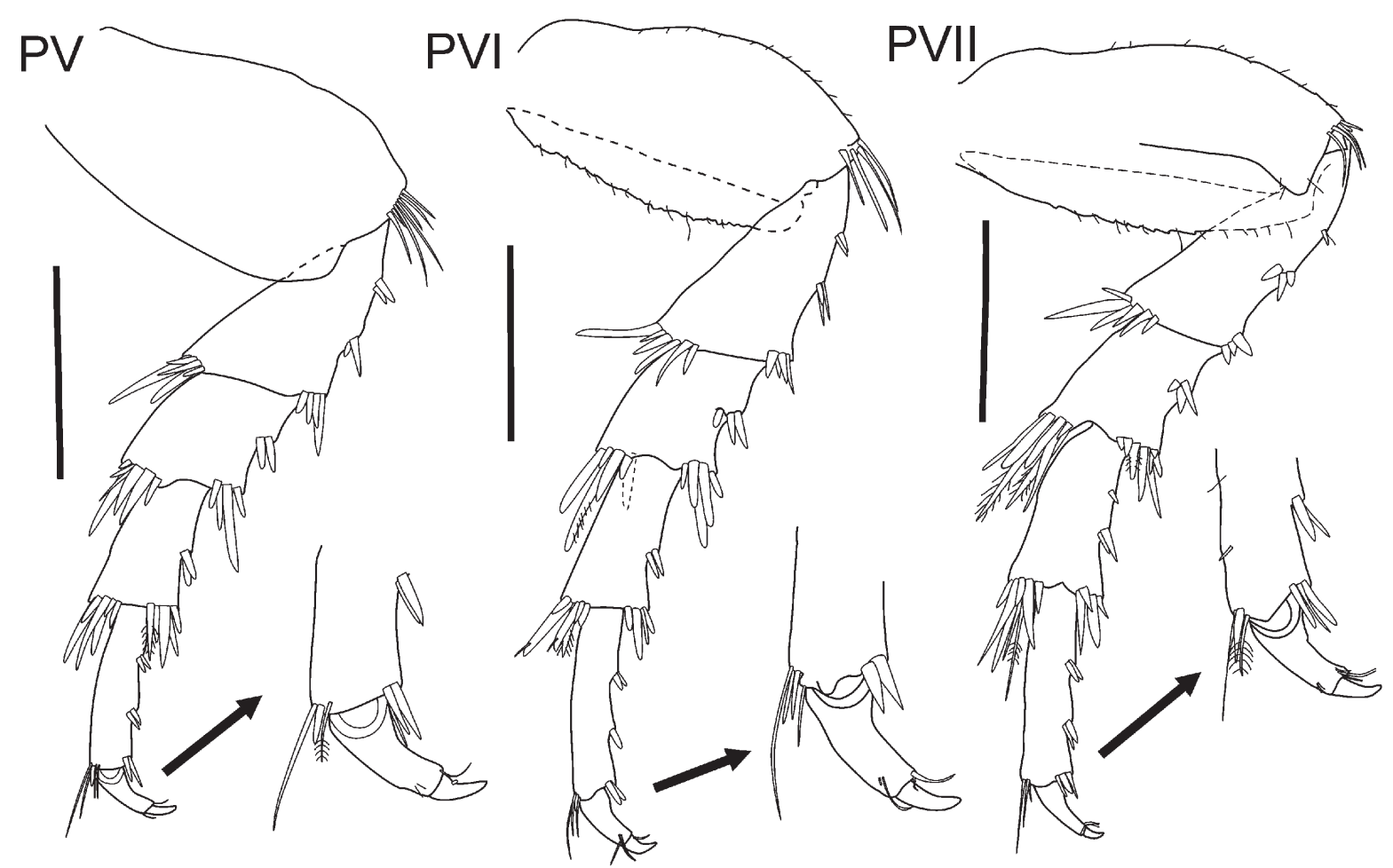

Figure 4. Cirolana lemoscastroi sp. nov., holotype, female (5.1 mm), pereopods V-VII, BPOT IV 37 (457”48”S - 3644'15”W), off Potiguar Basin, Rio Grande do Norte, MOUFPE 14956. Scale bars: $0.5 \mathrm{~mm}$.

off Potiguar Basin, Rio Grande do Norte, $8 \mathrm{~m}$ depth, 20 May 2004, N/RB Astro Garoupa, MOUFPE 14803. 1 male, \#34, dredge, 0740'20"S - 3443'20”W, off Pontas de Pedras Beach, Pernambuco, $20 \mathrm{~m}$ depth, 04 March 1969, MOUFPE 295 (previously identified as Cirolana parva by Koening, 1972). 1 ovigerous female, REC 61 PE, dredge, 807'50”S 3447'80"W, off Boa Viagem Beach, Recife, Pernambuco, calcareous algae, $25 \mathrm{~m}$ depth, 03 January 1967, MOUFPE 272. 2 males and 4 females, REC 85 PE, dredge $8^{\circ} 12^{\prime} 00^{\prime \prime} S$ - 34\%49'20"W, off Candeias Beach, Jaboatáo dos Guarapes, Pernambuco, calcareous algae, $27.5 \mathrm{~m}$ depth, 02 February 1967, MOUFPE 247. 1 male, REC 105 PE, dredge 8०00'50"S - 344' $10^{\prime \prime W}$, off Recife, Pernambuco, sand, $19.5 \mathrm{~m}$ depth, 24 February 1967, MOUFPE 279 (previously identified as Cirolana parva by Koening, 1972). 1 male, 2 ovigerous females and 1 juvenile, REC 106 PE, dredge $8^{\circ} 00^{\prime} 10^{\prime \prime} S$ - 34\%450"W, off Recife, Pernambuco, calcareous algae, $23 \mathrm{~m}$ depth, 24 February 1967, MOUFPE 256 (previously identified as Cirolana parva by Koening, 1972). 1 ovigerous female, REC 109 PE, dredge 7058'70”S - 34²'40"W, off Olinda, Pernambuco, calcareous algae, $29 \mathrm{~m}$ depth, 24 February 1967, MOUFPE 270 (previously identified as Cirolana parva by Koening, 1972). 7 males, 8 females and 5 manca, Revizee-Central Benthos, \#14 (1747’77”S - 3552'88”W), 07 July 2001, $60 \mathrm{~m}$ depth, N/RB. Astro Garoupa col., MNRJ 17456 (previously identified as Cirolana parva by Koening, 1972). 1 male and 1 female, Santa Cruz, Espírito Santo, 22 July 1979, MNRJ 3714 (previously identified as Cirolana parva).

Diagnosis. Body about 3 times as long as wide, poorly ornamented. Head anterior margin smoothly rounded; interocular furrow present, but incomplete; submarginal furrow present. Pereonite I with a visible oblique furrow and a ventral carina. Antennula short, just reaching pereonite 1 , peduncular article 1 and 2 fused. Antenna extending to pereonite 3. Pleonite 5 with 3 dorsal longitudinal crests. Pleotelson subtriangular, 1.3 times longer than wide, with two dorsal longitudinal crests; apex 

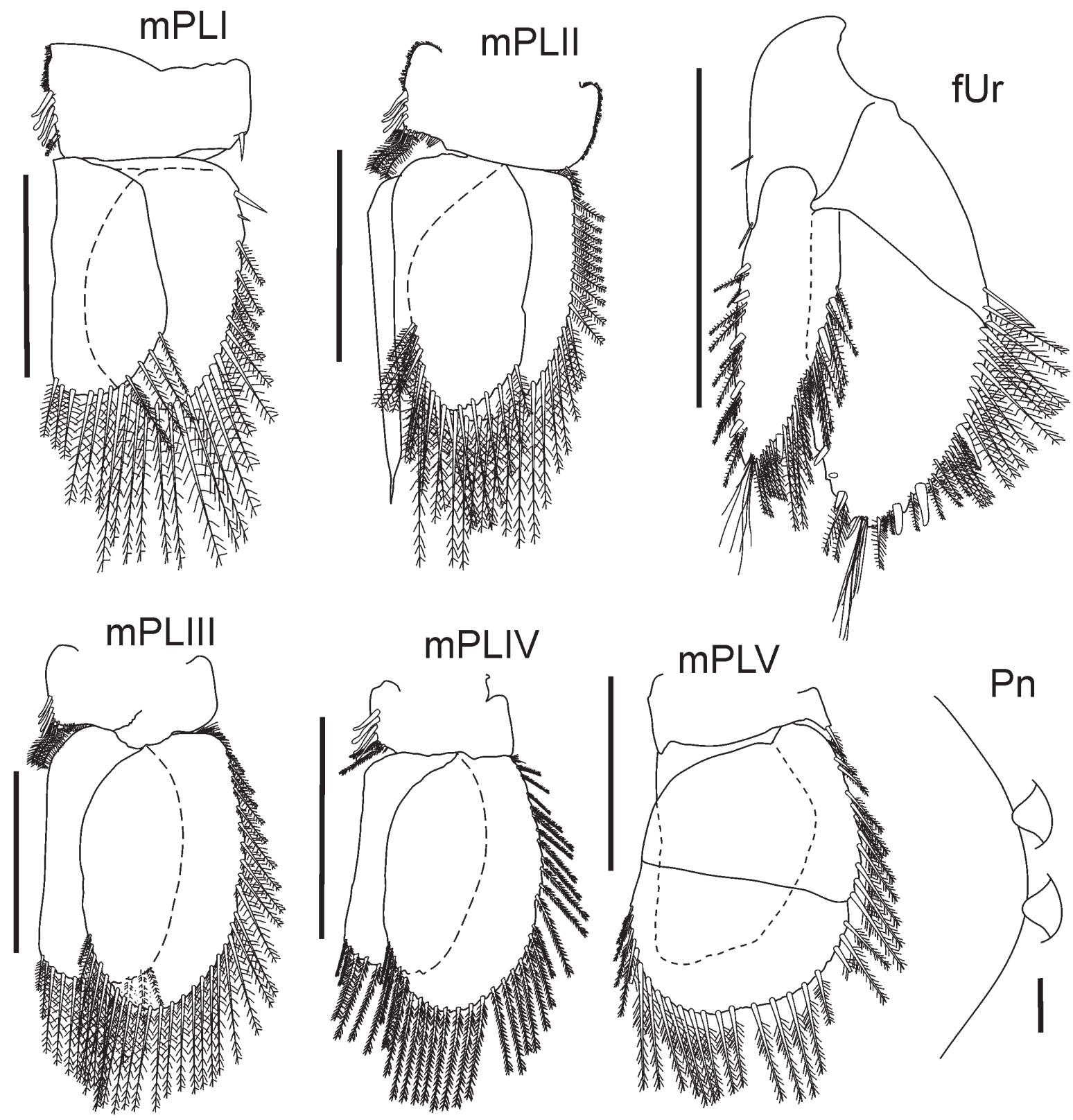

Figure 5. Cirolana lemoscastroi sp. nov., pleopods: paratype male ( $4.3 \mathrm{~mm})$, BPOT IV 37 (457" $48^{\prime \prime} \mathrm{S}-36^{\circ} 44^{\prime} 15^{\prime}$ W), off Potiguar Basin, Rio Grande do Norte, MOUFPE 14957. Uropod: holotype female $(5.1 \mathrm{~mm})$ from the same locality of holotype, MOUFPE 14956. Scale bars: $0.5 \mathrm{~mm}$.

with 8-10 robust setae and some short plumose setae. Pleopod V peduncle with 1 plumose seta on inner margin, exopod bilobate, endopod reduced and without setae.

Description. (based on holotype female $5.1 \mathrm{~mm}$ - MOUFPE 14956). Body about 3 times as long as wide, poorly ornamented. Head anterior margin smoothly rounded; interocular furrow present, but incomplete; submarginal furrow present. Pereonite 1 with a visible oblique furrow and a ventral carina. Coxal plates of pereonites 2-7 with oblique carina. Pereon smooth dorsally. Pleonite 1 hidden by pereonite 7 . Pleonite 5 with 3 dorsal longitudinal crests. Pleonite 2 posterolateral margin subacute. Pleonites 3 and 4 posterolateral margin rounded. Pleotelson subtriangular, 1.3 times longer the wide, with two dorsal longitudinal crests; apex with 10 robust setae and some short plumose setae.

Antennule short, just reaching pereonite 1 ; peduncular article 1 and 2 fused, longer than article $3(1.3 \mathrm{X})$; flagellum subequal to 
protopod, composed of 10 articles with dense aestethasts. Antenna extending to pereonite 3, flagellum composed of about 25 articles. Mandible asymmetric, left with incisor process 3-dentate; lacinia mobilis present; molar process with about 15 teeth; palp article 1 shorter than article 2 ( 0.8 times), with 2 slender setae on inner margin; article 2 longest, with setules on both margins; article 3 shorter than article 1 , with pinnate setae on outer margin, apex pointed and with a tuft of slender setae; right incisor process with sinuous margin between 2 teeth. Maxillula endopod with 3 stout plumose setae; exopod gnathal surface with 15 stout setae. Maxilla medial lobe with 2 long plumose setae and 12 slender setae; lateral lobes with 9 and 5 long setae distally, respectively. Maxilliped broad, endite with 2 coupling spines and 3 long setae apically; medial margin of base and article of palp with a line of setules; palp articles 2-4 with 6, 5 and 4 long setae, respectively, article 2 longer than articles 3 and 4 together, article 3 distomedial margin poorly produced.

Pereopod I basis moderately inflated, 2.1 times longer than wide, posterodistal angle with 4 setae; ischium widened distally, anterodistal angle produced over merus, posterodistal angle with a robust setae; merus posterior margin with 6 striated robust setae and 2 slender setae, both antero and posterodistal angle produced over carpus; carpus $0.5 \mathrm{X}$ shorter than propodus, triangular with one robust and one slender seta on posterodistal angle; propodus 2.2 times longer than wide, palm with 4 striated robust setae and one strongly striated robust setae near insertion of dactylus; dactylus robust with a subdistal blunt robust seta, unguis present and striated. Pereopod II basis moderately inflated, 2.2 times longer than wide, posterodistal angle with 4 setae; ischium widened distally, anterodistal angle produced over merus with a long robust seta and 2 short robust setae, posterior margin with 3 robust setae; merus posterior margin with 7 striated robust setae and one slender seta, anterodistal angle produced over carpus, with 4 robust setae; carpus short and triangular, posterior margin with one robust seta, posterodistal angle with 2 robust and one slender seta; propodus 2.5 times longer than wide, palm with one midway robust seta, posterodistal angle with 2 long setae, 2 robust short setae and one strongly striated robust seta; dactylus robust with 4 subdistal slender setae, unguis present. Pereopod III basis moderately inflated, 2.2 times longer than wide, anterior margin crenulated with small setae, posterodistal angle with 4 setae; ischium widened distally, anterodistal angle produced over merus with 2 long robust setae robust setae, posterior margin with 2 robust setae and 3 slender setae; merus posterior margin with 7 striated robust setae and one slender seta, anterodistal angle slightly produced over carpus, with 7 robust setae; carpus short and subsquare, posterodistal angle with 2 robust and one slender seta; propodus 2.8 times longer than wide, palm with 2 robust seta and 2 robust setae; dactylus robust with a subdistal blunt robust seta, unguis present and striated. Pereopod IV basis ovate, 1.9 times longer than wide, anterior margin smooth, anterodistal angle with 4 setae, posterior margin crenulated with small setae; ischium as wider as merus, anterior margin with 3 groups of robust setae (1-3-4), posterodistal angle with 3 robust setae; merus slightly shorter than ischium, anterior margin with 2 groups of robust setae (5-6), posterodistal angle with 6 robust setae; carpus less wider than ischium and merus, anterior margin with 2 groups of robust setae (4-4), posterodistal angle with 4 robust and one slender seta; propodus 5.5 times longer than wide, anterior margin with 3 groups of 2 robust setae; dactylus robust. Pereopod V basis ovate, 1.6 times longer than wide, anterior margin smooth, anterodistal angle with 7 setae; ischium as wider as merus, anterior margin with 3 groups of robust setae (2-2-4), posterodistal angle with 5 robust setae; merus shorter than ischium $(0.7 \mathrm{X})$, anterior margin with 2 groups of robust setae (2-4), posterodistal angle with 6 robust setae and one slender seta; carpus less wide than ischium and merus, anterior margin with 2 groups of robust setae (2-5), posterodistal angle with 6 robust setae; propodus 3.7 times longer than wide, anterior margin with 3 groups of 


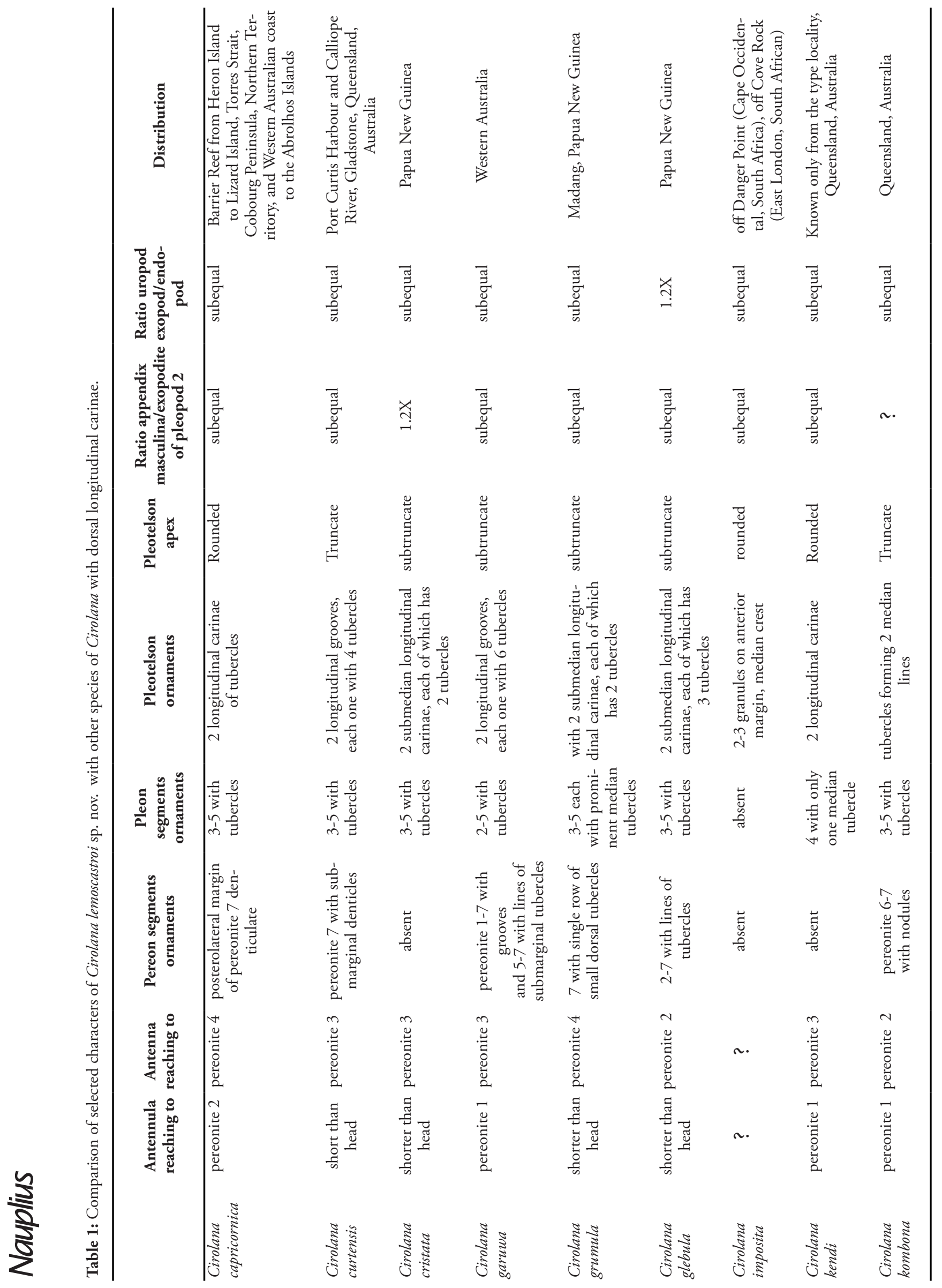




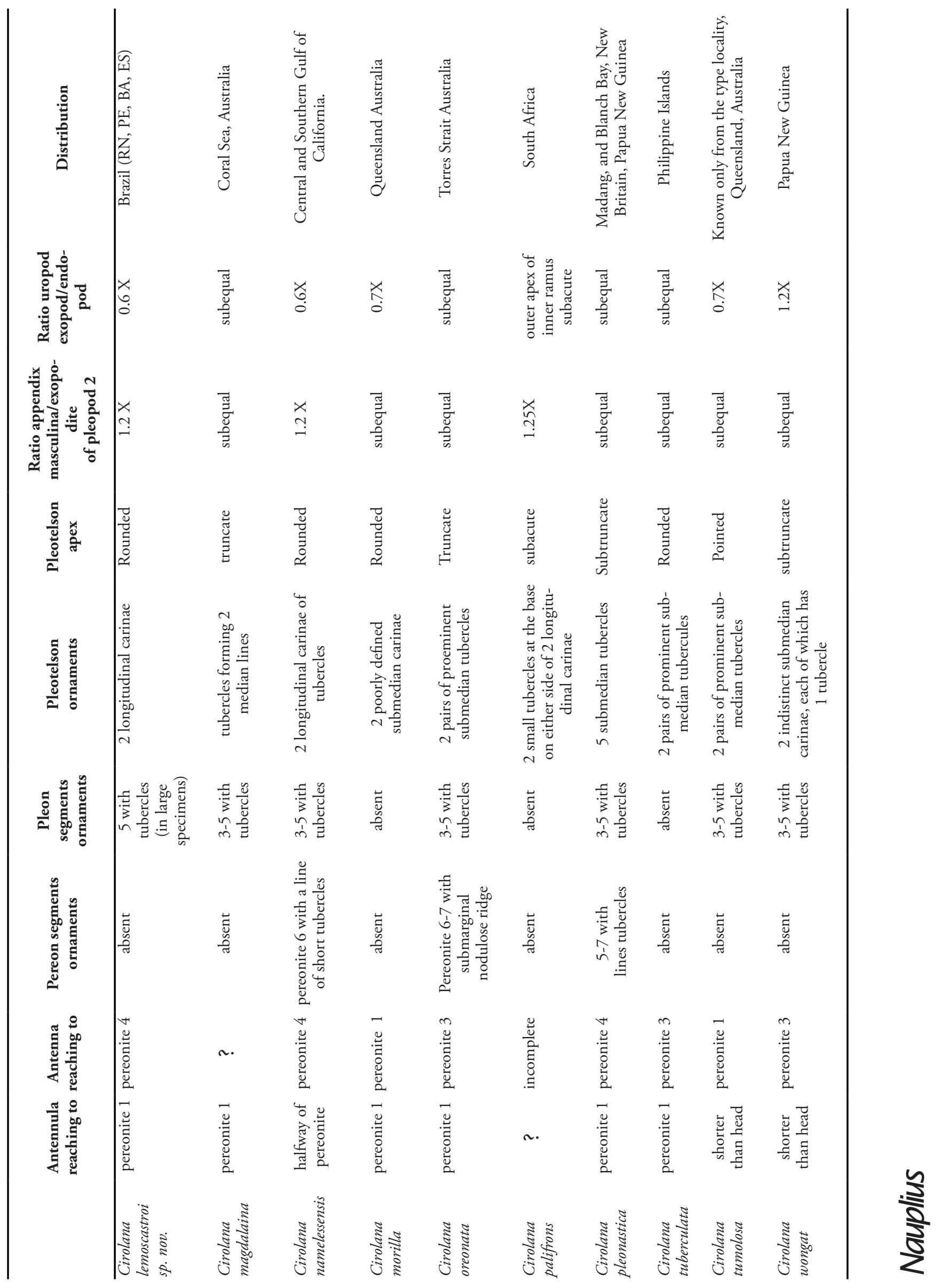


2 robust setae, posterodistal angle with one robust seta and 4 slender setae; dactylus robust. Pereopod VI basis ovate, 1.8 times longer than wide, anterior margin smooth, anterodistal angle with 4 setae; ischium as widened distally, anterior margin with 3 groups of robust setae (2-3-4), posterodistal angle with 5 robust setae; merus shorter than ischium $(0.7 \mathrm{X})$, anterior margin with 2 groups of robust setae (3-6), posterodistal angle with 5 robust setae; carpus less wider than ischium and merus, anterior margin with 2 groups of robust setae (2-6), posterodistal angle with 6 robust setae; propodus 4.4 times longer than wide, anterior margin with 3 groups of robust setae (2-12 ), posterodistal angle with 4 setae; dactylus robust. Pereopod VII basis ovate, 1.8 times longer than wide, anterior margin smooth, anterodistal angle with 4 setae; ischium as widened distally, anterior margin with 3 groups of robust setae (1-3-3), posterodistal angle with 6 robust setae; merus shorter than ischium $(0.5 \mathrm{X})$, anterior margin with 2 groups of robust setae (3-8), posterodistal angle with 7 robust setae; carpus less wider than ischium and merus, anterior margin with 3 groups of robust setae (1-2-4), posterodistal angle with 6 robust setae and plumose setae; propodus 4.1 times longer than wide, anterior margin with 3 groups of robust setae (2-2-3), posterodistal angle with 3 setae; dactylus robust.

Uropod protopod inner distal angle strongly produced with 3 plumose setae; inner ramus broad (1.8 times longer than wide) and pointed, longer than outer ramus, inner and outer margins with 5 and 3 robust, respectively, both with plumose setae; outer ramus narrow (3.4 times longer than wide) and pointed, with long plumose setae and 3 robust setae, inner margin with 2 robust setae.

Complementary description. Based on paratype male, $4.3 \mathrm{~mm}$ (MOUFPE 14957). Sexual dimorphism weak. Penes present, short and cone-shaped. Pleopod I protopod with 4 coupling hooks and 1 plumose seta on inner margin; single robust seta on lateral distal angle. Pleopod II protopod with 4 coupling hooks and 3 plumose setae on inner margin; single plumose seta on lateral distal angle; appendix masculina exceeding exopod by 0.13 of its length, tip narrowing to irregular point. Pleopod III protopod with 4 coupling hooks and 3 plumose setae on inner margin. Pleopod IV protopod with 4 coupling hooks and 3 plumose setae on inner margin. Pleopod $\mathrm{V}$ protopod with 1 plumose seta on inner margin, exopod bilobate, endopod reduced and without setae.

Morphological variations. In large specimens $(+6 \mathrm{~mm})$ the pleonites $3-4$ have small tubercles (See Lemos de Castro and Lima 1976) .

Geographic distribution. Potiguar Basin, Rio Grande do Norte to Espírito Santo (5º to 20S).

Depth range. Collected between 10 to 60 $\mathrm{m}$ depth.

Remarks. Cirolana lemoscastroi sp. nov. belongs to a group of species within the genus Cirolana characterized by the presence of two longitudinal crests dorsally on the pleotelson. This group comprises 18 species, such as: $C$. capricornica, C. curtensis, C. cristata, C. garuwa, C. grumular, C. glebula, C. imposita, C. kendi, C. kombona, C. magdaimina, C. namelessensis, C. morilla, C. oreonota, C. palifrons, $C$. pleonastica, C. tuberculata, C. tumolosa and $C$. wongat.

Cirolana lemoscastroi sp. nov. shares with $C$. imposita, $C$. kendi, $C$. morilla and $C$. tuberculata a rounded tip of the pleotelson rounded and the absence of tubercles on the pereonites. However, in C. lemoscastroi sp. nov. the appendix masculine is $1.2 \mathrm{X}$ longer than the exopodite of pleopod 2 and the uropod exopod is $0.6 \mathrm{X}$ of endopod length. Cirolana lemoscastroi sp. nov. is shares with C. namelessensis the appendix masculina 1.2 $\mathrm{X}$ longer than endopodite of pleopod 2 and exopod uropod $0.6 \mathrm{X}$ as long as endopod. However, in C. lemoscastroi sp. nov. the antenulla is shorter than the former species, reaching only pereonite 1 (vs halfway of 
pereonite 1) and antenna reaching pereonite 3 ( $v s$ antenna reaching pereonite 4 ).

An examination of the single specimen deposited in Crustacea Collection of the Museu Nacional do Rio de Janeiro, illustrated and described by Lemos de Castro and Lima (1976) as Cirolana palifrons, revealed that it fits with all diagnostics characters of the new species described herein. In their illustrations of pleonites, Lemos de Castro and Lima (1976) showed four tubercles dorsally, however we observed only three processes (longitudinal carinae). Bruce (1986) pointed out that the figured specimen by Lemos de Castro and Lima (1976) "do not agree with those of Barnard who described the species from a single damaged male from the Indian Ocean" (South Africa). Indeed, Cirolana lemoscastroi sp. nov. shares with Cirolana palifrons, two dorsal longitudinal carinae on pleotelson. However, Cirolana lemoscastroi sp. nov. clearly differs from the latter in not having: (a) the rostrum rounded produced and covering the peduncles of antennula and antenna, (b) antenna short, reaching only the $1 / 2$ of pereonite 1 (c) two pairs of dorsal tubercles in each side of pleotelson (d) rami of uropod subequal in length. Moreover, the new species described herein is characterized by the antenna extending to pereonite 3 and by the presence of 3 dorsal longitudinal carinae on pleonite 5 , whereas in $C$. palifrons the antenna 2 extending to pereonite 2 and pleonite 5 is dorsally smooth.

At a first glance, Cirolana lemoscastroi sp. nov. could be confused with $C$. parva, also recorded from Brazilian waters, since in some specimens (mainly subadults) the longitudinal carinae present on pleonite 5 and pleotelson are difficult to be seen, the new species also has only 4 segments visible on pleon and a similar shape of appendix masculina. Part of the material identified by Koening (1972) was re-examined here and corresponds to the new species. Therefore, perhaps, specimens of the new species deposited in Brazilian collections had been misidentified as $C$. parva. Despite of the ornamentation of the pleon and pleotelson, C. lemoscastroi sp. nov. can be distinguished from C. parva by incomplete interocular furrow on the head, and only exopod of pleopod 5 has a transversal suture (instead of pleopods 3-5).

A comparison of selected morphological characters 19 species, including the new species, with dorsal longitudinal carinae on the pleotelson is provided (Tab. 1).

Key to Cirolana species recorded from Brazilian Coast $\left(^{*}\right)$

1a. Head, pereon and pleon ornate with lines of tubercles............Cirolana (Anopsilana) browni $1 b$. Head, pereon and pleon smooth or only pleon ornate with some tubercles................. 2

2a. Pleonite 1 not hidden by pereonite $7 \ldots . . .$. Cirolana (A.) jonesi 2b. Pleonite 1 totally hidden by pereonite $7 \ldots$ 3

3a. Pleonite 5 with 3 dorsal crests; pleotelson with two dorsal longitudinal crests.................. Cirolana lemoscastroi sp. nov. 3b. Pleon and pleotelson smooth dorsally ...... Cirolana parva

(*) Cirolana minuta was not included in key since the material studied by Coelho et al. (1980) is lost. So, this record needs to be confirmed.

ACKNOWLEDGEMENTS - The authors are very grateful to Dr. Cristiana S. Serejo for loan the comparative material of Cirolana palifrons depositated in the Crustacean collection of Museu Nacional/UFRJ. The authors thank to Coordenaçáo de Aperfeiçoamento de Pessoal de Nível Superior (CAPES) by financial support.

\section{REFERENCES}

Almeida, A.O.; Santana F.S.; Paiva R.J.C.; Souza G.B.G.; Boehs, G. and Coelho, P.A. 2009. Range extension of the estuarine isopod Cirolana (Anopsilana) jonesi (Crustacea: Cirolanidae) in the western Atlantic Ocean. Marine Biodiversity Records, 2(1): 1-6.

Barnard, K.H. 1920. Contributions to the crustacean fauna of South Africa. No. 6. Further additions to the list of marine Isopoda. Annals of the South African Museum, 17: 319-438.

Bruce, N.L. 1986. Cirolanidae (Crustacea: Isopoda) of Australia. Records of the Australian Museum, 6(Supplement): 1-239. 
Brusca, R.C. and Iverson, E.W. 1985. A guide to the marine isopod Crustacea of Pacific Costa Rica. Revista de Biologia Tropical, 33(Supplement): 1-77.

Coelho, P.A; Ramos-Porto, M. and Koening, M.L. 1980. Biogeografia e bionomia dos crustáceos do litoral equatorial brasileiro. Trabalhos Oceanográficos da Universidade Federal de Pernambuco, 15: 7-138.

Coleman, C.O. 2003. "Digital inking": How to make perfect line drawings on computers. Organism, Diversity and Evolution, 3(Electronic Supplement 14): $1-14$

Holdich, D.M.; Harrison, K. and Iverson, N.L. 1981. Cirolanid isopod crustaceans from the Townsville region of Queensland, Australia, with descriptions of six new species. Journal of Natural History, 15(4): 555-605.

Keable. S.J. 1998. A third species of Aatolana Bruce, 1993 (Crustacea: Isopoda: Cirolanidae). Records of the Australian Museum, 50(1): 19-26.

Koening, M.L. 1972. Nota sobre a ocorrência de alguns isópodos no Norte e Nordeste do Brasil. Trabalhos Oceanográficos da Universidade Federal de Pernambuco, 13: 237-244.

Leach, W.E. 1818. Cymothoadées. In: Cuvier, F. (ed), Dictionnaire des sciences naturelle. Strasbourg et Paris, 12: 338-354.

Lemos de Castro, A. and Lima, I.M.B. 1976. Nova espécie de Cirolana Leach e ocorrência de Cirolana palifrons Barnard no litoral brasileiro. Atas da Sociedade de Biologia, 18:77-81.

Miller, M.A. 1968. Isopoda and Tanaidacea from buoys in coastal waters of the Continental United States, Hawaii, and the Bahamas (Crustacea). Proceedings of the United National Museum, 125: 1-53.

Pires-Vanin A.M.S. 1998. Malacostraca - Peracarida. Marine Isopoda. Anthuridea, Asellota (parts), Flabellifera (parts) and Valvifera, p. 607-626. In: P.S. Young (org), Catalogue of Crustacea of Brazil. Rio de Janeiro: Museu Nacional.

Stepien, C.A. and Brusca, R.C. 1985. Nocturnal attacks on nearshore fishes in southern California by crustacean zooplankton. Marine Ecology Progress Series, 25: 91-105. 